\title{
Into the Fog: Literature and Censorship in New Zealand
}

\author{
JAMES MEFFAN
}

\begin{abstract}
Despite the fact that New Zealand has an active censorship regime that has, in its time, banned or restricted some significant literary works, literary academics do not seem particularly engaged in censorship debates here. The 2015 case in which the Young Adult novel Into the River was reclassified four times during which process it was placed under an Interim Restriction Order suggests that perhaps greater attention is warranted. In this essay I argue that the current censorship legislation, the Films, Videos and Publications Classification Act, 1993, does not represent literature in a way that most academics would recognise and support, and nor is it consistent in its own terms.
\end{abstract}

"The real problem of censorship is that not all people agree," Ian Gordon told Salient, Victoria University's student magazine, in 1963, a statement that seems not only self-evident but transhistorically obvious. ${ }^{1}$ His reasons for making such an apparently redundant assertion become clearer if one considers the context. Professor Gordon was speaking of his role as chair of the Literature Advisory Committee, established to advise the Customs Department on controversial imported literary works. In 1959 the Minister of Customs chose to ban Vladimir Nabokov's Lolita against the advice of this committee. It was not until 1964 that the work was eventually made available without restriction under newly defined censorship laws and a regime that had replaced the executive power of the minister with the more distributed and democratic operations of the Indecent Publications Tribunal (IPT), a specialist body established to arbitrate in cases of material charged as indecent. Yet even though the IPT arrived at a majority decision to remove the ban on Lolita, the decision did not represent the unanimous conclusion reached by the whole tribunal. Two members of the tribunal-Prof. Gordon one of them - removed themselves from the hearing on the grounds that their views had already been made public in hearings under the previous law. The tribunal's chair, Judge A. P. Blair also registered strong disagreement with the ruling, and the tribunal felt it was warranted, given "the history of the book in New Zealand ... that both the majority decision and the dissenting decision should be set out" when the decision was written up. ${ }^{2}$

Perhaps such ongoing disagreement should come as no surprise; censorship debate by its nature always represents some misalignment between those who see a work as worth the production, publication, distribution and consumption, and those who feel on the contrary that some social value, some notion of "the public good," is best served by that work's amendment, nonselection, suppression, restriction or extirpation. What is surprising though is the extent to which disagreement persists between those who act in a professional capacity, under the guidance of the law and with access to a growing body of research and precedent, to assess and classify works. As the recent case of Young Adult novel Into the River by Ted Dawe demonstrates, whatever refinements have been made to state-managed censorship over the years, the law as it currently stands is still no reliable producer of consensus, particularly where works that lay claim to literary status are concerned. Indeed, I would suggest that the current law perpetuates a number of assumptions about literature and its effects that are not only out of step with current critical understanding but that may be mutually incompatible.

What Into the River also exposed was the breadth and depth of feeling that persists around questions of objectionability and censorship in society today. The fact that this relatively minor 
case drew international attention suggests that this level of contention is not limited to New Zealand. The advent of "below the line" commentary on media websites provides some indication of the level of interest, although not in any reliably representative way. The amount of friction that such a story generates, however, does seem to have some bearing on the degree of ongoing coverage it receives. In the case of Dawe's novel, that interest was evident from the extensive media coverage that the story gained. Yet despite this coverage, analysis of the underlying issues did not proceed much beyond familiar questions and answers about writers' freedoms and responsibilities and well-worn assumptions about fiction's capacity to influence behaviour. This essay is an attempt to provide a rather broader exposition of the issues raised by the case and to reflect on principles that might usefully be raised for consideration in the event of a revision of the law as it relates to the classification of literature. To do this I will provide a brief historical sketch of censorship legislation in New Zealand as it relates to literature before looking in greater depth at the case of Into the River in order to highlight what seem to me to be aspects of the debate, and possibly the law, that could benefit from reframing.

As was common in a number of countries, censorship law in New Zealand was drawn from mid-nineteenth-century English law, particularly the Obscene Publications Act, 1857. The earliest efforts to suppress obscene material in New Zealand appeared piecemeal in Customs regulations and the Vagrant Act, 1866 and the Police Offences Act, 1884. ${ }^{3}$ These laws were particularly concerned to regulate the display and dispersal of obscene representations in the public sphere, though as Christoffel notes, "[n]o attempt was made by legislators to define terms like 'obscene' and 'indecent." "4 This lack of definition is also evident in the first act to specifically and exclusively deal with offensive publications: the Offensive Publications Act, 1892. The act targeted "any picture or printed or written matter which is of an indecent, immoral, or obscene nature" (S 3). While literature fell within its ambit, its aim was clearly directed more towards public displays and advertisements than books. It was not until this act was replaced with the much more extensive Indecent Publications Act, 1910 (full title: An Act to Prohibit the Publication and Sale of Indecent Literature) that literature and literary values gained specific mention. It is frequently claimed that the 1933 trial of Joyce's Ulysses in the US represents a turning point in the treatment of literature in English-speaking jurisdictions. It was in this trial that Judge John Woolsey overturned an existing ban on the novel by allowing artistic merit, the attitude, intention and reputation of the artist, and the effect of the novel as a whole, as relevant concerns in the evaluation of a work. Yet consideration of "the literary, scientific, or artistic merit or importance of the document" was written into New Zealand's Indecent Publications Act more than two decades prior to the Woolsey decision and nearly five decades before similar provisions were included in English legislation. ${ }^{5}$

This is not to suggest, however, that New Zealand represented a bastion of liberal or progressive attitudes towards literary works. In 1928 Jean Devanny's novel The Butcher Shop was banned by the Censorship Appeal Board of Customs despite its content being not markedly more challenging than many other novels already in circulation at the time. The fact that the novel was banned under the Customs Act, 1913 rather than the Indecent Publications Act gives some idea of the dispersed way in which the state enacted the regulation of literature. Customs had established an advisory board to make recommendations in relation to imported literature. Yet with no clear guidelines on what constituted indecent, offensive or obscene material, or how to non-arbitrarily determine artistic merit or literary value, decisions tended to rely on the common-sense views of those charged with arbitrating such matters. There was, as a result, very little consistency in decisions made, leading to members of the public and interested bodies such as The New Zealand Library Association expressing a lack of confidence in state censorship processes. Dissatisfaction produced political pressure and pressure led to change. 
New Zealanders often express pride at being "early adopters" of progressive laws and social policy, and the updating of censorship laws in 1963 encouraged the belief that in this area we were world leaders. Gordon Tait, for instance, celebrates the introduction of the Indecent Publications Act, 1963 as "a statute which led the world in bringing order and reason to the administration of censorship and which has served as a model for other countries." ${ }^{6}$ For Tait, the "[d]uality in New Zealand Censorship" that had resulted from the range of legislation under which indecent material could be prosecuted represented the main failing in need of rationalisation. ${ }^{7}$ The variety of legislation and regulatory bodies involved meant that decisions were being made by Customs officers, police and judges using undefined terms to protect against unspecified ills. Yet while improvements to legislation, and specifically the constitution of the IPT, may have promised a more logical and even-handed means of differentiating the quality from the trash, Tait sees in the openness of the system to challenge by any member of the public the risk of a return to the inconsistency of earlier legislation. This risk was most dramatically realised by the indefatigable Patricia Bartlett whose crusade against almost any sexual content managed to significantly influence politicians (and through them, policy) over a number of years, an influence that was subsequently institutionalised with the establishment of the Society for the Promotion of Community Standards in 1971. The society remains active today. ${ }^{8}$

A more pressing concern with the new legislation was expressed in one of its earliest engagements. The dissension of IPT chair A. P. Blair against the decision to remove the ban on the novel Lolita has already been mentioned. Not only did Blair disagree with the evaluation of Lolita as "not indecent" by the majority of his committee, in his written opinion he articulated a fundamental misgiving about the wording of the legislation itself. Noting that the relevant section of the act states that "a book is indecent if ... it can be said that such a book deals with matters of sex, horror, crime, cruelty or violence in a manner which is injurious to the public good," he goes on to express doubt at the possibility of this formulation producing any robustly objective evaluation of literary works:

As I see it a real difficulty in any case under the Act is that some of the important phrases used in the Act mean different things to different persons. Whether a particular book is written in a way that is "injurious to the public good" is almost entirely a matter of individual opinion. The same can be said of the phrases "the dominant effect of the book as a whole," "whether any person is likely to be corrupted by reading the book," and "whether the book displays an honest purpose." In applying these phrases to a book under examination the personality, education and background of the individual judges of the book will decide how these phrases are to be interpreted. There is ample room for sincere differences of opinion. ${ }^{9}$

Blair's sense that such terms could produce only subjective responses was to some degree contradicted by the inter-subjective agreement reached between the other members of the committee. Yet given that no decisive interpretation of key terms is provided within the act he is surely right to suggest that any such agreement is heavily reliant on environmental factors, some of which might tend towards inter-subjective convergence (education), but others of which (personality, background) are just as likely to produce "sincere differences of opinion." If Blair's assumptions are correct, the only way to ensure consensus would be to appoint a committee on the basis of shared values, and similar education and upbringing. Not only would this undermine the democratic ideals behind the constitution of the committee in the first place, it would effectively acknowledge that the guidance provided by the law is insufficient to align 
the decision-making processes of a diverse (and therefore potentially representative) group of censorship professionals.

The documented decision of the IPT on Lolita offers a useful expansion on Blair's concerns. The majority decision underlines the fact that "Lolita is part of the literary work of a very distinguished writer" and implies that the novel in question may well be an "acknowledged literary masterpiece," an assessment that is based both on reputation and the sense, taken from reading the novel, that Nabokov "uses [language] with great skill and resource." Blair acknowledges that "[ $\mathrm{t}]$ here is general agreement that the book has considerable literary and artistic merit," and accedes that he must therefore, "defer to others who are better qualified to judge." Yet there is a calculated undermining of this proclaimed deference when he continues: "For myself I would not regard the novel as a great literary achievement. If I am compelled to classify the book's literary and artistic merit (a most invidious task) I should classify it as having literary and artistic merit but would not use any superlatives." Implicit in this personal acknowledgement is the suggestion that general agreement is no guarantee of objectivity and that the lack of transparency in the procedures of literary evaluation creates doubt that "expert" opinion can necessarily assure an accurate and defensible estimation of a work.

On the matter of the dominant effect of the novel as a whole and its likely effects on readers, Blair is again in frank disagreement with his tribunal. What they do share, though, is an assumption that it is reasonable to extrapolate from a novel (taken as a whole) to its real-world effects. For the committee, "[i]t is important ... that the central figure ... is represented as a pitiable figure.... Far from condoning that conduct, the author throughout implicitly reprehends it." Blair counters that in his view Nabokov "has made his characters appear in a not unsympathetic light," and that this makes it likely that "some minors and indeed some adults would be likely to be corrupted by the book." So while both parties accept that a reader is likely to be affected by the author's "position" encoded in the narrative they disagree on what that authorial position is. Similarly, Blair refutes the (highly questionable) claim by the committee that "the book has sociological and psychological significance," stating bluntly: "[a]s the book is a work of imagination it can have no medical, or scientific value." While each of these points is arguable, the grounds for argument have clearly not been sufficiently established to allow the committee to win their chair around, or vice versa. The effect of setting these opposing views out side by side, with only the assurance of numerical superiority on the side of the final decision, seems only (and perhaps somewhat paradoxically) to affirm Blair's concerns, and to show that the act under which he and his committee were operating lacked the necessary guidance for dealing with such fundamental differences of opinion.

Taken in its historical context this is a disappointing conclusion given that internationally the developing discourse of censorship in the twentieth century had the appearance of a late blooming of the project of secularisation and rationalism. At least since the watershed moment of the Ulysses trial in the US, concepts such as "artistic merit" and "the dominant effect" of works taken as a whole had begun to be admitted as part of successful defences of works of literature, offering an ameliorative to hitherto prevalent tendencies of moralisers to read the "dirty bits" out of context and assume the universality of their own normative values. Indeed while it might be tempting to see Blair's attitude as merely anachronistic, a throwback to these earlier times and attitudes, his dissension shows that it was precisely the criteria introduced to allow for special consideration of literary works that were muddying the waters in censorship discussions. 
Yet whatever problems there may have been with censorship legislation as it related to literature, regulation of offensive material in New Zealand was broadly taking a path of increasing liberalisation, particularly for works that could lay claim to artistic merit, following, as the process was designed to do, changing social attitudes (as assessed by the censors), implicitly required by the move from a clear-cut and ahistorical moral position to one based on social utility and injury. However, as Watson and Shuker argue, moral and political positions shade into one another through the concept of "the public good." ${ }^{10}$ And as moralist Patricia Bartlett demonstrated, a case could be made that representations felt by a minority (but substantial) group to be offensive produce a demonstrable harm: the feeling of offense itself. Tait's complaint that moralists like Bartlett were derailing the process of rational evaluation purely by being more vociferous than others, may simply point to an unavoidable correlative of the democratisation of the process.

The criteria provided to guide the state's censorship professionals towards a more sympathetic response to specifically literary concerns were largely reproduced in the next update of censorship legislation, the Films, Videos and Publications Act, 1993, the legislation under which literature is classified today. While the later law retains the general tenor of the earlier in its definition of target material and the criteria to be applied, some notable amendments to terminology were made. Most immediately apparent is the replacement of the term "indecent" with "objectionable." Yet while this suggests a move from a categorical to a relational assessment, the definition given to an objectionable publication as one that, "describes, depicts, expresses, or otherwise deals with matters such as sex, horror, crime, cruelty, or violence in such a manner that the availability of the publication is likely to be injurious to the public good," is almost identical to the definition given to an indecent work in the earlier law. In the later law, too, the personification evident in the 1963 act's requirement that publications should be assessed for whether they display "an honest purpose and an honest thread of thought" is replaced by the assessment of "the purpose for which the publication is intended to be used." Some vestige of that tendency to personify works remains, however in the 1993 act's concern with "the character of the publication." At the procedural level there were also a number of changes: The IPT was replaced with the more plentifully staffed and resourced Office of Film and Literature Classification (the Classification Office), and where previously appeals had been heard by the Supreme Court, a Film and Literature Board of Review was now established to provide an escalation path for those dissatisfied with decisions reached by the Classification Office.

From my perspective as a literary academic, much of the terminology relating to literature and its effects now appears dated and theoretically dubious. Yet despite this apparent anachronism and the fact that a number of works of significant academic interest have been restricted or suppressed by the censor, there has been relatively little attention from literary academics to this classificatory process or to the laws that govern it. This may be because the trend to more liberal reassessment generally seems to result in satisfactory outcomes regardless; although Lolita, and Bendan Behan's Borstal Boy were at one time banned, both works subsequently had their classifications reviewed and the bans removed. It may also be because in cases such as Bret Easton Ellis's American Psycho, which still wears an R18 rating, few academics are in significant disagreement with some level of restriction given the highly disturbing nature of a number of passages in the novel. Regardless of whether academics disregard the process through complacency or agreement, cases continue to arise in which the treatment of a work of literature highlights deficiencies and ambiguities in the terms of reference and the process itself. 
In New Zealand literary circles there is usually a flurry of parochial excitement when one of "our" works rates a mention overseas. The brief but intense media attention garnered by the ongoing disagreement over the classification of Ted Dawe's YA novel Into the River in 201315 proved less than pleasing to many, however. In particular, the placing of the novel under an Interim Restriction Order by the President of the Film Literature Board of Review drew national and international interest. New Zealand, it was suggested with some condescension in a number of international publications, is a country that still bans books: Middle Earth stuck in the middle ages. The Guardian even ran a quiz inviting readers to "pick quotes from Ted Dawe's banned novel Into the River." The quiz required readers to distinguish excerpts from Dawe's novel from other passages ranging from Lady Chatterly's Lover to The Bible, demonstrating among other things the tone-deafness of the New Zealand censors in prohibiting distribution of this novel when other works that covered similar ground went unrestricted (and were generally applauded). ${ }^{11}$ Numerous New Zealand readers felt moved to express their anger, dismay and even shame in the "below the line" commentary sections of online articles at what was seen as a retrograde and reactionary response to a legitimate literary work (not to mention a relatively mild one), the author of which had the entirely laudable intention of getting young males to read.

When an unrestricted classification was finally delivered by the Board of Review in late 2015, the fourth review of the novel in a round of classification ping-pong that had run between the Classification Office and the Board of Review since 2013, there was a widespread feeling that common sense had at last prevailed and the right decision been reached. Moreover, predictably, Dawe and his novel had gained more media coverage than most writers could hope to achieve in an entire career, reportedly being "flooded with commercial offers" as a result. ${ }^{12}$ Misreading the Interim Restriction Order as a complete, long-term ban on the novel, many commentators made much of the fact that it had been twenty-two years since another novel had been banned in New Zealand and wondered whether this heralded a return to a more conservative and restrictive approach by the censors.

While it was this interim restriction that captured public attention, this was perhaps the least controversial aspect of the process, merely a prudent safeguard if the risks claimed by the novel's detractors proved to be real. Much more alarming is the indecisiveness of the classification process and what that says about the criteria on which it is based and the openness of the law to divergent interpretation. The possibility of appeal is of course a democratic strength; the Board of Review offers the assurance of an avenue of appeal for those who do not agree with decisions reached by the Classification Office. Yet this is no simple escalation path. While all film is required to be classified, works of literature are only reviewed in response to external complaints or requests. Having been self-published in 2012, Into the River was submitted for review by the Secretary for Internal Affairs in July 2013 following a "complaint by a member of the public who was concerned at the description of sexual activity in the story." 13 In these circumstances the Classification Office is required to examine and classify the publication. The original complainants (in this case Family First and the Society for Promotion of Community Standards) and others identified as having a particular interest in the publication (the author and publisher) were notified of their right to make written submissions on the classification of the book. Having measured the publication against the criteria outlined in the Films, Videos, and Publications Classification Act the Classification Office concluded that, "Into the River's unrestricted availability is unlikely to injure the public good" and classified the novel M (unrestricted: suitable for mature audiences 16 years of age and over). ${ }^{14}$ Crucially, it was determined that actions represented in the novel did not qualify as "objectionable" because they did "not meet the threshold where they can be interpreted as 
promoting or encouraging, or upholding or strengthening" those actions in society. ${ }^{15}$ In applying the $\mathrm{M}$ rating, however, the Office did indicate that it accepted in principle the idea that younger readers might need protection from the novel's "stronger content." 16 The report offers no commentary on how the need for protection squares with the assessment that "unrestricted availability is unlikely to injure the public good."

Family First responded (as they were entitled to within the 30 day time limit) to this decision by appealing to the Board of Review who, in their review, were much clearer about the basis for providing protection for children and young people, and consequently their ruling was more decisive and proscriptive. ${ }^{17}$ The Board received submissions from Family First, Dawe and the Classification Office. Having determined that the novel was not objectionable in the more general terms of section 3(1) of the Act they considered section 3B which allows for the likelihood of injury in more specific situations including that where "the general levels of emotional and intellectual development and maturity of persons under the specified age mean that the availability of the publication to those persons would be likely to cause them to be greatly disturbed or shocked." 18 In classifying the novel R14 the board identified fourteen as the age at which they felt readers would have attained sufficient "emotional and intellectual development" and would thus be unlikely to be "greatly disturbed or shocked." What was not revealed until the release of the board's second review decision in 2015 was that the submission by the Classification Office to the 2013 sitting of the Board of Review had sought to have the novel classified R16 as the "correct" classification, contradicting their earlier position. ${ }^{19}$ In documenting their 2015 decision the Board also notes that it

did not have the original decision of the Classification Office before it at the review meeting, since ... decisions of the Classification Office are not directly relevant to reviews by the Board. Accordingly, the Board was not aware that the actual decision which the Classification Office had made differed from the reference to it in its submissions. ${ }^{20}$

While the Board is careful to explain that this omission is strictly within the terms of its remit, it does seem like an extraordinary oversight. How can a review by the country's foremost censorship professionals, and authors of the original classification, not be relevant to a classificatory review?

The board's decision to instead apply an R14 restriction represented a majority view, although one board member had been unable to attend the hearing due to fog, and the president of the board registered a dissenting view. In his written opinion, board president Dr Don Mathieson argues for an R18 classification, in line with the views of Family First, insisting that, "[i]t is injurious to the public good to normalise, as the book does, sexual intercourse by young teenagers. Even if it is prevalent in our society it is injurious to depict it as a normal activity for 13- or 14-year olds to engage in because this tends to encourage wholly undesirable experimentation." ${ }^{21}$ Ignoring for the moment the more circular aspects of this argument, and the assumed difference between prevalence and normalcy, Mathieson's response highlights an area of concern that is generally made insufficiently explicit in these reports: what are the mechanisms by which fictional literature is understood to be able to cause injury? Other members of the Board of Review seem to follow an argument, implicit also in the decision of the Classification Office, that in order to justify restriction the reviewer should be able to discern in the text some active process of persuasion and endorsement for the proscribed behaviours, that the novel is deploying its rhetorical resources in a way that signals an intentional desire on the part of the author to promote and encourage (in this case) teenage sexual activity and drug use. Mathieson's assumption allows for a more passive view of 
influence: that beyond any active attempt to promote a particular behaviour, simple representation can produce a sense that the represented behaviour is normal. He also shares the board's view that those of insufficient maturity are likely to be "greatly disturbed or shocked" by the content, but assesses the appropriate age at which readers can be expected to have gained adequate "emotional and intellectual development and maturity" as eighteen rather than fourteen years.

The act allows for decisions - made either by the Office or the Board - to be reconsidered by the Classification Office. As an acknowledgement that decisions reflect general social attitudes of the moment, it is accepted that changing attitudes may eventually necessitate reclassification. Interested parties can seek a review of a classification after three years, or sooner if they can demonstrate to the satisfaction of the Chief Censor that, "there are special circumstances justifying reconsideration of the decision." 22 In this case the Chief Censor was persuaded in particular by a submission from the General Manager, Libraries and Information, Auckland Council, on behalf of Auckland Libraries that the R14 rating set by the Board of Review had had the unexpected consequence of limiting access for those readers over fourteen due to the way that restricted texts must be managed by public libraries. At the heart of this argument was a reminder that censorship always mediates between competing injuries: any injury that might result from exposure to the content of the publication must be weighed against the injury of infringing on the fundamental human right to freedom of expression as articulated in the New Zealand Bill of Rights Act 1990. The second decision of the Classification Office openly, damningly and unequivocally criticises the Board of Review for failure to attend to these obligations:

At no point in the Board's decision (or in the dissenting opinion of minority view) is the right to freedom of expression referred to. It is thus entirely unclear, on the text of their decision, whether the right to freedom of expression was considered by the Board when applying the FVPC Act. This is in contradiction to their obligations under the NZBORA.... If the right to freedom of expression has not been considered in coming to the classification decision, it is an error of law. ${ }^{23}$

In arriving at its decision to reclassify the work as unrestricted, the Office questions whether the R14 rating of the Board "is in due proportion to its objective of preventing injury to the public good." ${ }^{24}$ In seeking to rebalance the scales between protection and freedom of expression, the Office acknowledges that the treatment of Into the River is exceptional, and therefore in the terms of the law, exceptionable: "there is a plethora of material readily available to those under the age of 14 years ... dealing with similar or the same content as this publication." ${ }^{25}$ Disproportionality, then, is identified both in terms of unequal treatment before the law and in the compromising of a human right when there is a satisfactory alternative in " "professional curation' and adult supervision." ${ }^{26}$ Although nominally justified by the introduction of "special circumstances" outlined by the Auckland Libraries submission, it is readily apparent that the review offers an overt critique of the approach of the Board of Review, barely suppressing a sense of irritability at the intrusion of a part-time, intermittently convened body on the work of professional civil servants who approach their work in full knowledge of the legislation and who have well-oiled machinery for dealing with this sort of thing.

It must, then, have been a profound irritant to the Classification Office when the Board of Review again accepted the task of $r e$-reconsidering the classification at the request of Family First. Moreover, what had been a relatively low-profile case (although one steadily drawing the attention of a widening circle of interest groups) was suddenly thrust into the international spotlight thanks to the Interim Restriction Order. The idea of a "book ban" seemed to have 
particular imaginative resonance among media and public, particularly once it became apparent that the novel in question was, while potentially challenging to its target audience, relatively benign in the broader context of the sorts of material usually classified as objectionable, or that which was freely available to youth through an ever-widening number of channels for that matter. By the time the Board released its second decision, this time upholding the unrestricted classification, media interest had largely moved on, leaving a vague sense among national and international audiences that New Zealand suffered under some of the most restrictive classification laws in the world.

Should this bad press matter when, from a liberal, democratic perspective, the desired result was achieved though a process that allowed the novel's opponents the opportunity to have their concerns aired and seriously considered? Is this drawn-out, back-and-forth process simply a demonstration of appropriately consultative democracy in action? The fact that there is a Chief Censor, a Classification Office and a Board of Review is evidence that however the times change, the problem is still "that not all people agree," particularly with respect to the representation of "matters such as sex, horror, crime, cruelty, or violence." The legislation that calls these organs into being represents an attempt to clarify the principles on which their judgments are made and in doing so acknowledges that clarification is necessary. While there is nothing wrong per se with a process that involves challenge and revision of earlier decisions, there is something about the way this process played out that suggests that the law is not sufficiently clear, and the relationships between the different functionary groups insufficiently defined, to give a sense that the law, in cases such as these, knows what it is doing.

Law, in many cases, admits of a process of self-examination and self-correction. The operations of state censorship that attempt to remain responsive to evolving public opinion must of necessity be open to change and development. The question here is not whether the law is perfect, or even perfectible, but whether it is workable in the social environment within which it operates, and also whether it makes sense in its own terms. The possibility of perfection was, in effect, lost when it was accepted that in matters of indecency and offence the law was not dealing with absolute values but socially contingent ones, requiring the change to the more socially responsive concept of "objectionability." Blair's concern that many of the law's terms could not be applied in an objective manner may be justified, but his sense that things should be otherwise may be too ambitious. Whether a book is injurious to the public good may not be answerable with absolute objectivity or certainty. ${ }^{27}$ Nevertheless, a vast amount of analysis has been produced that attempts to supply evidentially supportable answers. While these analyses have varied widely in their assumptions and conclusions, by 1988, the Ministerial Committee of Inquiry into could confidently assert that after "millions of dollars of research ... a near consensus among social scientists has emerged," at least regarding the relationship between television watching and aggressive behaviour in children. ${ }^{28}$ Despite this confidence, the matter is far from settled and research continues to be produced that supports radically different positions in the debate. Yet the fact that research is being conducted means that efforts are being made to refine methodologies and data is accumulating so that, at any given historical moment, the censor can consider questions about effect in an informed manner, weighing up evidence that runs beyond the limited domain of personal opinion.

Most of these studies are concerned with the more extreme representations of sex and violence. The sex and violence in Into the River is at a level that appears very tame by comparison. Yet the fact that the novel is classified YA - targeted at adolescents - introduces questions of the emotional maturity of readers and their capacity to deal with the representations. Here too research is available to allow for the development of evidentially supported arguments. On the 
evidence of past censorship decisions, however, it appears that there is more of a tendency for assessors to revert to speculation and assumption about likely effects when young people are taken into consideration. Section 3(2) of the current act calls for censorship of any publication that, "promotes or supports, or tends to promote or support" certain specified activities. Both Blair, talking about Lolita, and Mathieson, considering Into the River, are very certain that the material under consideration has a high likelihood of promoting the behaviours it describes among readers who have not yet attained adulthood. Blair employs a metaphor of contagion to convey his sense of how literature might work to infect susceptible readers:

In my view immature persons should be guarded as much as possible from the infection of sexual perversion until they are strong enough to resist infection. I believe that young persons are susceptible to infection. They are at an age of experiment, an age of indiscretion and an age of increasing sexual impulse. While the great majority of young persons would be unaffected by Lolita, some would not be. The reader of a book about sexual perversion is in a sense participating in the perversion. I do not suggest for a moment that merely reading about sexual perversion can be compared with physical participation in it. I do suggest that just as physical participation in such perversion can be harmful, mental participation in the form of reading about it could also do harm to susceptible minors. ${ }^{29}$

The logic is highly suggestive, but not really supportable. It is notable that similar claims of influence are not usually directed at, for instance, factual, textbook accounts of perversion. Concern is much more frequently directed at narrative, and narrative fiction in particular. This is understandable given fiction's capacity to engage the imagination through a wide variety of rhetorical means. On the one hand this has led to the requirement to treat literary works "as a whole"; it is understood that their effects are achieved through all component parts working together. But this also makes literary fiction highly susceptible to different reading approaches, as the differences of opinion among Tribunal and Board of Review members attests. While the criterion to consider the whole of a novel represents an important protection against the tendency to take parts of it out of context, it is a principle that seems to assume that a group of readers will, or should, arrive at similar assessments of "the dominant effect" of novels. Whether this should be the case, it plainly has not been.

This indicates an area in which the act and the censorship process it guides seem poorly reconciled. Since the earliest legislation there has been little guidance on how specifically to determine whether material is obscene or indecent. The test, derived from the Hicklin standard, has hitherto been some evaluation of the likelihood (or "tendency") of the work to deprave or corrupt, an assessment that until recently has largely been left to the intuition of the censor. The move from categorical terms like "indecent" or "obscene" to relational ones such as "offensive" or "objectionable" implicitly demands wider reference to social mores and norms. Yet within the demos there is, predictably a wide range of opinion, not to mention different levels of investment in making those views heard. While the opening up of the process to democratic consultation makes it less susceptible to the idiosyncrasies of individual opinion, there is still a need for a professional group to weigh competing arguments and arrive at defensible conclusions. The ongoing evidence of division within and between groups of censors attests to the fact that the criteria for evaluation are unable to provide clear, unambiguous guidance on some key issues.

Blair accurately identifies some of these areas in his dissenting opinion on Lolita, and it is worth noting that it is, in particular, those criteria that respond to questions about the treatment of literature, most famously derived from the trials of Ulysses, that continue to be problematic. 
This is not simply because the law and its officers are insufficiently sensitive to literature's peculiar qualities. In the latter half of the $20^{\text {th }}$ century a number of developments in literary criticism radically challenged many of the assumptions underlying censorship principles most sympathetic to literature. These developments strengthen rather than allay the misgivings expressed by Blair about the usefulness and reliability of the assessment criteria on the basis of which censors decide how to treat works brought before them. The "theory wars" of the ' $80 \mathrm{~s}$ and '90s produced a great deal of debate about such concepts as literary merit, the significance of the artist's name and reputation, the author's intention, the status of disciplinary expertise and the bases on which hermeneutic efforts might be mobilised and adjudicated. In all of these arguments, the idea that the relevant qualities are immanent in texts is resoundingly challenged. Viewed instead as catalysts for reading practices that might differ significantly in important ways, texts cannot of themselves guarantee the specifics of their reception or the uses to which they are put, except in the broad ways that language use relies on some degree of alignment of grammar and lexicon. Intention is no proof against "misuse".

The requirement that censors attend to "the dominant effect of the publication as a whole" arose from a recognition that to do so would require attention to complex structural aspects of literary works that produce a variety of effects including, significantly, irony. Attention of this sort reveals that characters and even narrators can say what the text as a whole does not "really mean". The push to attend to a work's own artistic procedures derived in significant part from aestheticism, a critical position that was strongly articulated during the Ulysses trials. Yet aestheticism also insists that a properly aesthetic response is antithetical to the "kinetic" 30 impulses of more worldly, interested reading strategies that characterise the pornographic and didactic modes. Yet it is to avowedly didactic arguments that censors typically turn in the final determination of whether a representation is likely to be "injurious to the public good", as is evident from the disagreements discussed above.

As a literary academic, there is something uncomfortable and disorienting in witnessing debates about works towards which I have a professional interest, but hearing them discussed in terms that seem theoretically dubious and internally incoherent. But do the means matter when the results are generally unexceptionable? Deborah Gordon of the Classification Office feels that the results speak for themselves; the vast majority of material submitted for classification has been, "puerile sexual material" Gordon assures us: "The Office of Film and Literature Classification holds the complete collection of publications classified between about 1969 and 1975, and with few exceptions there is nothing of literary, educational or social merit to be found, except perhaps Down Under the Plum Trees and The Little Red Schoolbook". ${ }^{1}$ What are the evaluative bases for this comfortable assessment? A more theoretically up to date view of literature would insist that value, like reading itself is contingent on an array of social factors. Examination of these factors is essential to understanding how a work operates in society, and whose interests are served by the assertion of one set of values over another.

\footnotetext{
${ }^{1}$ George Quinn, "Book Censorship in New Zealand-Prof. Gordon Describes Present System," Salient 26, no. 6 (1963): 5.

${ }^{2}$ Decision No. 2: In the Matter of The indecent Publications Act 1963 and in the Matter of the book

Lolita by Vladimir Nabokov, np.

${ }^{3}$ Paul Christoffel, Censored: A Short History of Censorship in New Zealand. (Wellington:

Department of Internal Affairs, 1989), 3-8.

${ }^{4}$ Ibid., 3.
} 
${ }^{5}$ Office of Film and Literature Classification, "From The Butcher Shop to The Peaceful Pill: A History of Book Censorship in New Zealand" (paper presented at the LIANZA 2010 Conference, November 2010) http://www.classificationoffice.govt.nz/PDFs/LIANZA-2010-OFLC-paper.pdf (accessed February 25, 2016), 2.

${ }^{6}$ Gordon Tait, The Bartlett Syndrome: Censorship in New Zealand (Christchurch: Caxton Press, 1979), 6.

${ }^{7}$ Ibid.

${ }^{8}$ See Carolyn Moynihan, A Stand for Decency: Patricia Bartlett and the Society for Promotion of Community Standards 1970-1995 (Wellington: Society for Promotion of Community Standards, 1995) for a full and sympathetic account of the influence of Bartlett and her society.

${ }^{9}$ Stuart Perry, The Indecent Publications Tribunal: A Social Experiment (Wellington: Whitcombe and Tombs, 1965), 104.

${ }^{10}$ Chris Watson and Roy Shuker, In the Public Good? Censorship in New Zealand (Palmerston North: Dunmore Press, 1998), 13.

${ }^{11}$ Alison Flood, "Can you pick the quotes from Ted Dawe's banned novel Into the River?" The Guardian 8 September, 2015, http://www.theguardian.com/books/2015/sep/08/can-you-pick-thequotes-from-ted-dawes-banned-novel-into-the-river, (accessed December 11, 2015).

${ }^{12}$ Kim Knight, "Hollywood comes calling for 'banned book' Into the River," Stuff September 15, 2015. http://www.stuff.co.nz/entertainment/books/72085118/Hollywood-comes-calling-for-bannedbook-Into-the-River, (accessed December 11, 2015).

${ }^{13}$ Office of Film and Literature Classification, "Notice of Decision: Into the River, 2013," OFLC, http://www.censor.org.nz/PDFs/Into-the-River-OFLC-decision.pdf (accessed February 25, 2016), 2. ${ }^{14}$ Ibid., 11.

${ }^{15}$ Ibid., 5.

${ }^{16}$ Ibid., 11.

17 "Anyone seeking a review of a publication must do so within 30 working days of publication of the List of Decisions in which the classification appears." While not made explicit, this implies that members of the public have a right to seek a review after each classification by the Classifications Office (i.e. that any classification or reclassification might be closely followed by a review. http://www.dia.govt.nz/diawebsite.nsf/wpg_URL/Agency-Film-and-Literature-Board-of-ReviewIndex (accessed February 25, 2016).

${ }^{18}$ Films, Videos, and Publications Classification Act, 1993, s3B(4)(a).

${ }^{19}$ I have been assured, however, in conversation with the Classification Office, that this was merely the unfortunate result of a typographical error, not the dramatic change of position it appeared. Perhaps the relevant point here is that communication between Office and Board is so minimal that this simple mistake was not immediately cleared up. The fact that the Board then chose to mention it as an apparent vacillation in its 2015 report is suggestive of a level of antagonism between the two functionary groups.

${ }^{20}$ Film and Literature Board of Review, "Decision of the Film and Literature Board of Review: Into the River, 2015," http://www.censor.org.nz/PDFs/Into-the-River-2015-BOR-majority-decision.pdf (accessed February 25, 2016), para. 18.

${ }^{21}$ Film and Literature Board of Review, "Dissenting Opinion of Dr Don Mathieson, President: Into the River, 2015," http://www.censor.org.nz/PDFs/Into\%20the\%20River-2015-BOR-dissentingdecision.pdf (accessed February 25, 2016), para. 1.

${ }^{22}$ Films, Videos, and Publications Classification Act, 1993 s42(3)(b).

23 "Notice of Decision: Into the River, 2015," OFLC, http://www.censor.org.nz/PDFs/Into-the-RiverOFLC-reconsideration-decision-2015.pdf (accessed February 25, 2016), 8.

${ }^{24}$ Ibid., 9.

${ }^{25}$ Ibid., 9.

${ }^{26}$ Ibid., 9. In reality, Joan Gibbons suggests, this balance between curation and supervision is already well established and accepted in New Zealand society: "Most New Zealanders take a common sense approach towards censorship and book selection. Few schools would deliberately antagonise their clientele, but equally few would expect parents to interfere with teacher decisions about purchases. Public libraries expect to cater to a variety of tastes and beliefs. They generally agree that it is the business of parents to control their own child's reading, while it is the business of the library to 
provide for all" (404). Joan Gibbons, "Censorship and Book Selection in New Zealand," Para*doxa, 2, no. 3-4 (1996): 399-405.

${ }^{27}$ In the educational resource book, Censorship, McLachlan and Scott readily acknowledge that in the requirement to consider "whether any person is likely to be corrupted by reading the book or hearing the sound recording, and whether other persons are likely to benefit therefrom," "two undefined and probably indefinable terms are balanced." The assessment required, they concede, must be speculative: "[a]ll the Tribunal can do is to guess whether sex, horror, crime cruelty and violence are so emphasised in the book before it as to be likely to do some undefined moral harm to some unknown readers, or so treated as to do some undefined moral good to other readers." Their response is typical of a number of commentaries in that it acknowledges what seems to be a major flaw in the legislation without offering any commentary on possible remedies. Bruce McLachlan and W. J. Scott, Censorship: A study of Censorship of Books, Films and Plays in New Zealand (Auckland: Heinmann, 1973), 9.

${ }^{28}$ For a summary of the wide variety of such analyses, see Maurice Yaffé and Edward C. Nelson, The Influence of Pornography on Behaviour (London: Academic Press, 1982), xii and 171-248; the quotation is from the Report of the Ministerial Committee of Inquiry into Pornography (1988), 51. ${ }^{29}$ Stuart Perry, op. cit. 106.

${ }^{30}$ The term is Joyce's, spoken by Stephen Dedalus in A Portrait of the Artist as a Young Man (205), in the course of a lecture he is giving his school-mate Lynch on aesthetics. The fact that the novel presents an argument against reading artistic works didactically adds a teasing element of metalepsis to the reading experience. James Joyce, A Portrait of the Artist as a Young Man (Harmondsworth: Penguin, 1960).

${ }^{31}$ Deborah Gordon, "Injuring the Public Good? Censorship and Libraries in New Zealand," LIANZA, http://www.lianza.org.nz/sites/default/files/injuringthepublicgood_dgordon.pdf (accessed December 11, 2015). 